\author{
Andrzej KONDEJ, PhD \\ Faculty of Economics and Management, University of Bialystok \\ e-mail: andrzej.kondej@uwb.edu.pl \\ ORCID: 0000-0002-8979-3590
}

DOI: $10.15290 /$ oes.2018.04.94.21

\title{
MULTI-FORMATTED CHARACTER OF THE CONCENTRATION OF RETAIL FOOD MARKET IN POLAND
}

\begin{abstract}
Summary
The paper discusses the issue of concentration of the retail food market in Poland. This phenomenon is dominated by the international operators of large-surface networks. However, the entities managing small-format networks are increasingly involved in it. The aim of the study is to identify and assess the multi-format nature of the concentration of this trade.

The conducted analysis uses the results of own quantitative and qualitative research on the retail food market. The study includes the figures regarding the market as a whole, the results and data of particular networks and numerical analyses within commercial formats.

The paper shows an ongoing process of market concentration with the participation of economic entities managing networks in all commercial formats in the years 2010-2017. Additionally, it was found that the intensity of this phenomenon presents a declining tendency, which results from the diversified structure of the retail food market in Poland.
\end{abstract}

Key words: concentration of the market, trade networks, formats, market structure

JEL classification: F10

\section{Introduction}

The concept of concentration is considered as the process of increasing the economic force and market position of the largest companies. The level of this phenomenon is determined by the degree of domination of these operators over other participants in a certain sector. Concentration is the effect of accumulating of economic resources by large entities and of centralizing the decision-making processes. As the consequence of ownership changes, there is observed the loss of economic independence of the subordinated entities in favor of the decision-making center. The concentration in retail trade is the phenomenon connected with the development of the market, simultaneously with the decreasing number of its participants. In this situation, those participants that in economic terms are the weakest are losing their competitive capability. As the effect, some trading posts are either closed or combined with larger trading groups. Therefore, the concentration 
leads to permanent structural and quality modifications in this sector [Kucharska, Twardzik, 2007, p. 80].

The aim of the elaboration is to show that owing to the competitive character of the market and to the dynamics of the adjustment processes, the phenomenon of concentration regards all commercial formats functioning on the retail food market in Poland. Owing to the diversified structure of this sector, here this phenomenon develops in an entirely different way than in other European countries. The development activity of the large-surface networks managed by international trade corporations must lead to a substantial change in the structure of this market. However, the scale and dynamics of concentration depend on many factors that include, among others: the strategies of the operators of the largest trade networks, the life cycle of the formats on the market, the intensity of competition or the consolidation activities at the level of small and medium grocery stores [Szulce, 1998, p. 60]. Large importance is attached also to the acquisition preferences of consumers who (by means of their purchase decisions) have considerable influence on either success or failure of trade companies functioning on the market [Gardocka-Jałowiec, 2015, p. 78].

\section{The forms, scale and dynamics of the concentration of the retail market}

The concentration may have also the investment or the association character [Kucharska, Twardzik, 2007, p. 80]. In the former case, it is considered as organic growth by means of creating new trading posts, opening logistic centers or expanding distribution channels. ${ }^{1}$ The development of the association type is mainly connected with fusions and acquisitions. This phenomenon is also affected by the development of franchising, agency or partnership networks created by new entities of uniform organizational and formal structure.

The strategic aim of the undertaken concentration activities is to increase the competition value of trading companies. The anticipated effect of it should be in the economies of scale, including especially: the cost rationalization, the improvement of the conditions of supply and supply prices as well as reduction in the prices of the offered products. Another essential motive of undertaking such activities is the achievement of the effect of experiences by means of improving management, achieving unique know-how or access to certain markets or distribution channels [Wspótdriatanie gospodarcže..., 1992, p. 31]

In terms of organization, the entities concentrating the retail market may select one of the following four basic strategies of development:

- organic development,

- franchising,

- $\quad$ the purchase of the existing networks (acquisitions),

1 The illustration is the formation of new stores within such networks as Biedronka, Żabka or Dino. 
_ joint ventures with a foreign partner [Strategie konkurencij..., 2005, p. 32].

The concept of organic development is related to investing by means of creating own trading objects. New trading spots may be established by ether construction or adaptation of the existing areas in accordance with the concept of the conducted trading activity.

Franchising is the method of consolidating the previously independent stores within the frameworks of a certain commercial network. It is the form of market expansion without the full involvement of own financial resources of the organizer of a trade group because it is based chiefly on the investments made by franchise holders. This concept enables fast development of the network which, as the consequence, brings a rapid increase of market shares of the entire group [Domański, 2001, p. 94].

The purchase of the existing networks (development via acquisition) is a form of market concentration that is undertaken by large operators on target markets. It ensures quick access to certain market segments, the takeover of the existing distribution system and the continuation of activity at the higher level of the retail sale [Zentes et al., 2013, p. 84].

The joint venture with a foreign partner is a strategic solution that enables increasingly better adjustment of the commercial activity to the specific character of the local market. It is possible thanks to the know-how, the familiarity with the market and the experience of the local partner. ${ }^{2}$

The measurement of the phenomenon of concentration on the retail food market must include the fragmented structure of this sector. For the needs of the conducted analyses, the $\mathrm{Cr}$ concentration ratio was used - it means the value share of ten operators in the market ${ }^{3}$ [Urbaniak, 2004, p. 288]. The analysis was conducted in the years 2010-2017, which enables assessment of the dynamics of the phenomenon. Additional assessment of the sector's structural changes was connected with working out the market shares of particular commercial formats.

The measured food market concentration level has increased in a noticeable way for the last eight years. In 2010 ten largest operators had only $36 \%$ of shares, while in 2017 already $58.8 \%$ (chart 1). In terms of the value, in this period the largest enterprises increased their retail sale by $109.9 \%$, while the total value of the food market increased only by $16.5 \%$.

2 On the Polish market the development activities in this formula are realized by such networks as: Intermarche and E. Leclerc.

3 Market shares are measured on the basis of the retail sale (in current prices). 
CHART 1

The value shares of ten largest enterprises in the retail food market in Poland in the years 2010-2017 (\%)

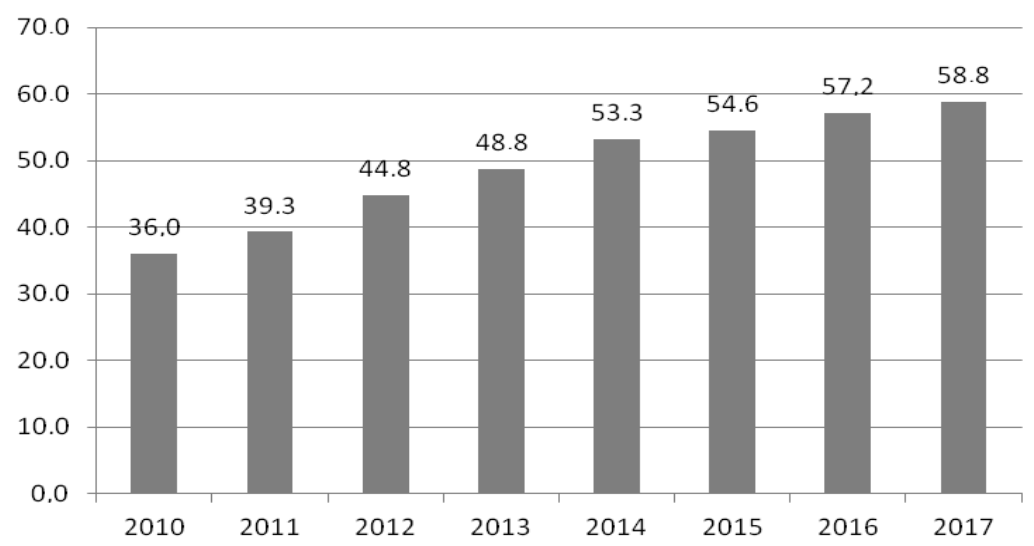

Source: own elaboration on the basis of: [Baza sieci detalicznych, 2018]

This figure unequivocally confirms the thesis that the development of the largest commercial entities took place at the cost of weakening the market position of the weakest participants of the market. In 2017 the total number of food stores was 11.5 thousand lower than in 2010. The largest regression was experienced by smallformat stores having less than $300 \mathrm{~m}^{2}$ of the sales space. In all the other formats the number of commercial outlets at the end of 2017 was larger than in the first year of the analyzed period.

CHART 2

Changes in the value shares of ten largest enterprises in the retail food market in Poland in the years 2010-2017 (percent points)

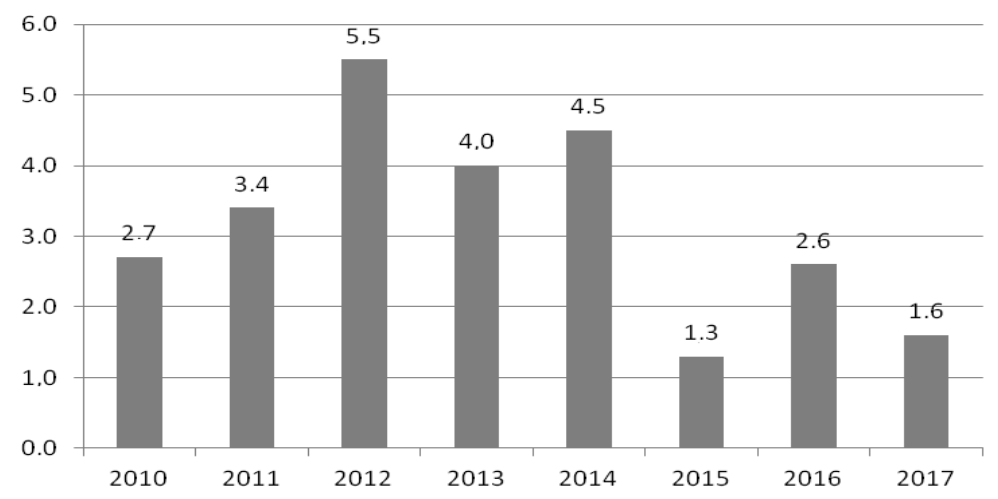

Source: own elaboration on the basis of: [Baza sieci detalicznych, 2018] 
The phenomenon of concentration on the Polish food market is characterized by the dynamics that has decreased since 2015 (chart 2). The reason for it is mainly the stagnation of hypermarkets and the decreasing rate of growth of discount stores [Driesiec sieci..., 2016]. In recent years the possibilities of organic development in these formats were becoming depleted. It results from the increasingly more visible symptoms of market saturation in terms of the number of stores. The effect of the increasing competitiveness of transnational trading corporations is the constant reduction of the number of small and medium-sized food stores managed by domestic owners. On the other hand, the expansion of operators of large-surface networks results in the competitiveness reaction of the enterprises managing networks in smaller formats. It concerns especially consolidation processes in the form of the development of the franchise and partnership networks.

\section{The largest trading entities concentrating the market}

The analysis of development activities of the largest operators of Polish food market enables the observation of a diversified growth dynamics of their market shares in the years 2010-2017.

TABLE 1

Retail sale and value shares of ten largest enterprises in the retail food market in Poland in the years 2010 and 2017 ( $\mathrm{mln}$ PLN)

\begin{tabular}{|c|l|c|c|c|c|c|}
\hline \multirow{2}{*}{$\begin{array}{c}\text { Position } \\
\text { in 2017 }\end{array}$} & \multicolumn{1}{|c|}{ Operators } & \multicolumn{2}{|c|}{$\mathbf{2 0 1 0}$} & \multicolumn{2}{|c|}{$\mathbf{2 0 1 7}$} & $\mathbf{2 0 1 7 / 2 0 1 0}$ \\
\cline { 3 - 7 } & \multicolumn{1}{|c|}{$\begin{array}{c}\text { Retail } \\
\text { sale }\end{array}$} & $\begin{array}{c}\text { Share } \\
\text { in the } \\
\text { market } \\
\mathbf{( \% )}\end{array}$ & $\begin{array}{c}\text { Retail } \\
\text { sale }\end{array}$ & $\begin{array}{c}\text { Share } \\
\text { in the } \\
\text { market } \\
\mathbf{( \% )}\end{array}$ & $\begin{array}{c}\text { Change } \\
\text { in } \\
\text { percent } \\
\text { points }\end{array}$ \\
\hline 1 & Jeronimo Martins Polska S.A. & 19,210 & 8.8 & 45,847 & 18.0 & 9.2 \\
\hline 2 & Eurocash S.A. & 8,357 & 3.8 & 28,390 & 11.2 & 7.4 \\
\hline 3 & Lidl Sp. z o.o. Sp. k. & 6,093 & 2.8 & 14,619 & 5.7 & 2.9 \\
\hline 4 & Tesco Polska Sp. z o.o. & 10,959 & 5.0 & 11,616 & 4.6 & -0.4 \\
\hline 5 & Auchan Polska Sp. z o.o. & 5,421 & 2.5 & 11,298 & 4.4 & 1.9 \\
\hline 6 & $\begin{array}{l}\text { Kaufland Polska Markety } \\
\text { Sp. z o.o. }\end{array}$ & 5,658 & 2.6 & 10,339 & 4.1 & 1.5 \\
\hline 7 & Carrefour Polska Sp. z o.o. & 7,677 & 3.5 & 9,325 & 3.7 & 0.2 \\
\hline 8 & Żaka Polska Sp. z o.o. & 2,340 & 1.1 & 6,982 & 2.7 & 1.6 \\
\hline 9 & $\begin{array}{l}\text { Polska Sieć Handlowa Nasz } \\
\text { Sklep S.A. }\end{array}$ & 2,619 & 1.2 & 6,581 & 2.6 & 1.4 \\
\hline 10 & SCA PR Polska Sp. z o.o. & 2,963 & 1.4 & 4,626 & 1.8 & 0.4 \\
\hline & Total & 71,297 & 32.6 & 149,623 & 58.8 & 26.2 \\
\hline
\end{tabular}

Source: own elaboration on the basis of: [Baza sieci detalicznych, 2018] 
Jeronimo Martins Polska S.A. increased Biedronka network in the analyzed period by $71 \%$. In that period the retail sale of this company increased by $139 \%$ in current prices (by 134\% in fixed priced from 2010), which is synonymous with considerable improvement in the sale effectiveness. The network is developing considerably faster than the food market on the whole, which resulted in a substantial increase of the market share from 8.8\% in 2010 to $18 \%$ at the end of 2017 (table 1). The operator of discount stores focus on organic growth by means of construction and opening of new outlet trading posts. The company is developing also thanks to the acquisition of other stores, however, such activities play only a marginal role. ${ }^{4}$

Eurocash S.A. is the largest organizer of small-format networks and supermarkets in Poland. ${ }^{5}$ This operator managed to increase the share in the market from $3.8 \%$ in 2010 to $11.2 \%$ at the end of the analyzed period (table 1). Such intensive expansion of presence on the market was possible thanks to the usage of various concentration forms, taking into consideration organic growth, acquisition and franchising. The most visible increase of market shares in the years 2010-2017 was possible thanks to the purchase of trade networks Groszek and Lewiatan from Tradis Group in 2011. The other consolidation activities regarded the networks of supermarkets Eko and Mila in 2017.

Lidl Polska Sp. z o.o. sp. k. achieved noticeable almost 6\% share in the market owing to the consistent organic growth. The managers of this network managed to create the format of a discount store having attractive and diversified product offer for the vast majority of Polish consumers. The German group's problem of development type is becoming the market saturation in larger towns and nonadjustment of the stores' size to small towns.

Tesco Polska Sp. z o.o. is listed among 10 largest operators owing to a large number of trading posts (419 in 2017) and to the high value of the turnover. However, the British company is no longer a leading entity that concentrates the Polish food market. Its shares decreased from $5 \%$ in the first year of the analyzed period to $4.6 \%$ in 2017 (table 1). Above all, it is the result of market problems of Tesco in Poland that began in 2014 and are connected with not adjusting the concept of activities to the needs and expectations of the local consumers.

Auchan Polska Sp. z o.o. doubled its market shares after the acquisition of Real network in 2014. It constitutes the example of the largest acquisition (in terms of the scale) on Polish food market in the second decade of the $21^{\text {st }}$ century. Since that time the further organic growth of this network in Poland has been contained. Owing to the concentration of market activity on the stagnation format of large hypermarkets, the operator had no longer possibility of further growth.

4 The example of the development of Biedronka network by acquisition is the acquisition (in 2018) of five supermarkets from the network Piotr i Pawel and the opening of a new trading concept in these places - they were termed as Biedronka Premium, comp.: [Kulisy sprzedasiy sklepów..., 2018].

5 The company manages both directly and indirectly several trading groups: abc, Groszek, Euro Sklep, Lewiatan and Delikatesy Centrum. 
Kaufland Polska Sp. z o.o. possesses large-surface stores in the unique compact format that may effectively compete with both hypermarkets and discount stores. It facilitated the growth of this company from $2.6 \%$ in 2010 to $4.1 \%$ at the end of the analyzed period (table 1). In accordance with the strategic concept initiated in 2015, the target destinations of this network's expansion in the organic form are larger towns having more than 100,000 inhabitants.

Carrefour Polska Sp. z o.o. constitutes the example of the company that undertakes various consolidation activities. For many years The French operator in a diversified way has developed its activity in all trading formats in Poland. Depending on the size of retail outlets, the methods of its activity on the market are diverse. In large formats (hypermarkets and supermarkets) there was realized organic growth by means of opening own trading posts, whereas the networks of small-format stores (Carrefour Express and Globi) - by means of franchising.

Żabka Polska Sp. z o.o. which administers two networks of convenience stores (Żabka and Freshmarket) became the largest beneficiary of the changing trends in the purchase behaviors of Polish consumers. Their increasing inclination to impulse shopping makes it possible to open two convenience stores each day. It may be assumed that in the specific convenience format this company almost entirely dominated the domestic market as it manages the network having 4906 small stores at the end of 2017.6 The high rate of growth was still noticeable also in the subsequent months, which is visible in the number of 5220 trading posts named Żabka and Freshmarket in November 2018.

Polska Sieć Handlowa Nasz Sklep S.A. is the only company having solely Polish capital among ten largest retail companies functioning in Poland. The strategic aim of the parent Group Specjal is the market consolidation in the format of small and medium-sized food stores. The network Nasz Sklep concentrates the market in the form of franchising by differentiating methods of cooperation with the owners of the stores depending on the size and location of the trading activity. The dynamic numerical growth of this group confirms the efficiency of the market concentration in the format of small-format stores.

SCA PR Polska Sp. z o.o., as the operator of Intermarche network, constitutes the example of the market concentration in the form of cooperation with the local business partners. Its market growth was hampered in 2015, whereas the operator focuses its activity on the modernization of the existing trading posts. Owing to the insignificant dynamics of numerical growth, Intermarche network is presently not listed among the entities that are still concentrating Polish retail market.

6 Calculation on the basis of: [Baza sieci detalicznych, 2018; the phone call surveys].

7 On the basis of: [www 1]. 
TABLE 2

\section{Forms of concentration used by ten largest companies in food retail market in Poland}

\begin{tabular}{|c|l|l|l|}
\hline No. & \multicolumn{1}{|c|}{ Operators } & \multicolumn{1}{|c|}{ Commercial networks } & \multicolumn{1}{|c|}{$\begin{array}{c}\text { Concentration } \\
\text { forms }\end{array}$} \\
\hline 1 & Jeronimo Martins Polska S.A. & Biedronka & organic growth \\
\hline 2 & Eurocash S.A. & $\begin{array}{l}\text { Groszek, abc, Delikatesy } \\
\text { Centrum, Lewiatan, Euro Sklep }\end{array}$ & $\begin{array}{l}\text { franchising } \\
\text { acquisitions } \\
\text { organiczny } \\
\text { growth }\end{array}$ \\
\hline 3 & $\begin{array}{l}\text { Lidl Polska Sklepy Spożywcze } \\
\text { Sp. z o.o. }\end{array}$ & Lidl & organic growth \\
\hline 4 & Tesco Polska Sp. z o.o. & Tesco & organic growth \\
\hline 5 & Auchan Polska Sp. z o.o. & Auchan & organic growth \\
\hline 6 & $\begin{array}{l}\text { Kaufland Polska Markety } \\
\text { Sp. z o.o. }\end{array}$ & Kaufland & organic growth \\
\hline 7 & Carrefour Polska Sp. z o.o. & Carrefour, Globi & $\begin{array}{l}\text { organic growth } \\
\text { franchising }\end{array}$ \\
\hline 8 & Żabka Polska Sp. z o.o. & Żabka, Freshmarket & franchising \\
\hline 9 & $\begin{array}{l}\text { Polska Sieć Handlowa Nasz } \\
\text { Sklep S.A. }\end{array}$ & Nasz Sklep & franchising \\
\hline 10 & SCA PR Polska Sp. z o.o. & Intermarche & joint venture \\
\hline
\end{tabular}

Source: own elaboration on the basis of: [Baza sieci detalicznych, 2018].

The analysis of the activity of the largest trading companies enables formulation of the conclusion that the main form of their activity on the market is organic growth. There may be observed also a clear link between the format of managed trading posts and the form of the development activity. With regards to largesurface stores (hypermarkets, supermarkets and discount stores) the dominating type of growth is organic growth. The growth by means of franchising is the domain of the operators functioning in smaller trading formats. It enables the fast increase of retail networks without considerable involvement of the organizer in terms of investments.

\section{Market concentration in the perspective of trade formats}

The analysis of the dynamics of the development of food trade in the years 20102017 shows the irregularity of growth of particular trading formats (chart 3). It illustrates the changing structure of the Polish market in terms of both value and volume. As the consequence, the impact of network operators in particular formats on the process of market concentration is different. 
In terms of the number of trading posts, the networks of convenience stores show the largest dynamics. The intensive quantity growth may be observed also in the case of discount stores. However, the rate of this phenomenon is weakening. The number of supermarkets is increasing considerably slower, whereas the networks of hypermarkets do not present the tendency to grow (chart 3) [Polski rynek handlu..., 2016, p. 8]. This clearly shows that the aforementioned formats are developing at the cost of small-format stores, whereas the effect of this phenomenon is the total decrease in the number of food stores in Poland. Additionally, it can be observed that the transformations on the Polish market have the character of surface concentration. The reduction in the number of stores is accompanied by the increase in the total sales surface. In the years 2010-2017, the number of trading posts decreased by $11.4 \%$, whereas the total sales surface increased by $5.8 \%$. It is the evidence of the increasing share of large-surface stores and concentration processes taking place mainly in large trading formats.

\section{CHART 3}

\section{The dynamics of the number of stores in particular formats of retail food trade in the years 2010-2017 (in comparison with 2009)}

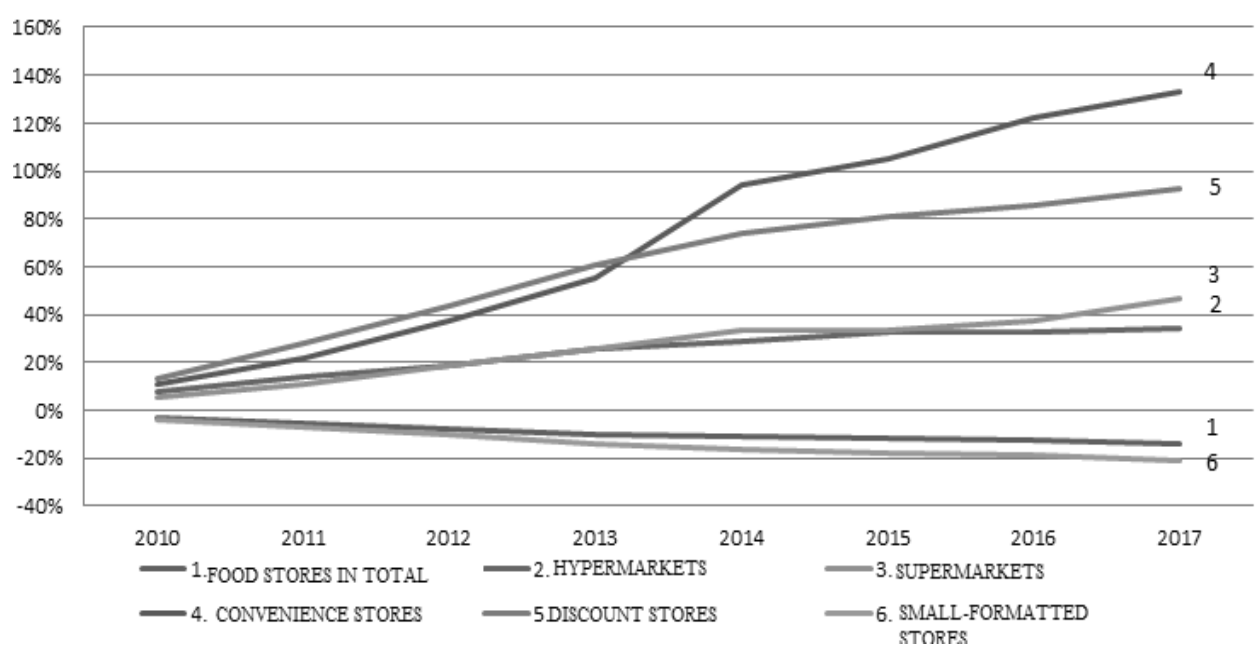

Source: own elaboration on the basis of: [Baza sieci detalicznych, 2018].

The in-depth analysis of the concentration of the Polish market of food sales is possible on the basis of the evaluation of such phenomena taking place within particular trading formats.

\section{Hypermarkets}

The format of hypermarkets was increasing its value share in the market till 2014, whereas since that year the constant decreasing tendency may be observed (chart 4). It means that the dynamics of sales of large-surface stores is lower than the rate of 
the market's growth on the whole. The regression results from the weakening competition position of stores with the largest sales surface. It is the direct effect of two external factors: increasing competitiveness of stores representing other formats (discount stores in particular) and the noticeable change in the purchase preferences of Polish consumers. It regards chiefly their inclination to do shopping frequently in the stores located near the place of residence. Owing to the stagnation processes in this format, the operators of the network of hypermarkets cease to have a considerable impact on the concentration process of the Polish market.

CHART 4

\section{The value share of hypermarkets in the retail food market in the years $2010-2017(\%)$}

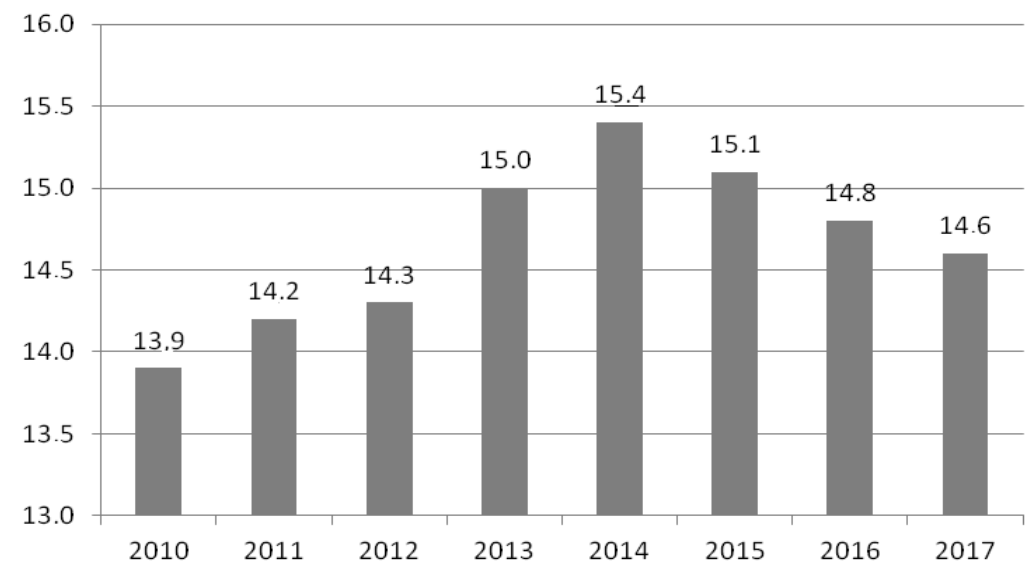

Source: own elaboration on the basis of: [Baza sieci detalicænych, 2018].

\section{Supermarkets}

The market share of supermarkets has stabilized since 2012 at the level slightly higher than $12 \%$ (chart 5). This phenomenon is the effect of considerable dispersion in the format where there are many networks of average size, but none of them has a clear competitive advantage. The format is characterized by major instability, which is noticeable in major ownership transformations and market difficulties of the weakest operators. The examples of such phenomena are the acquisition of Stokrotka network by the Lithuanian Group Maxima, the acquisition and rebranding of networks Eko and Mila by Eurocash S.A as well as serious economic difficulties of Piotr i Paweł network and the purchase of this company by the investment fund. 
CHART 5

The value share of supermarkets in the retail food market in the years $2010-2017(\%)$

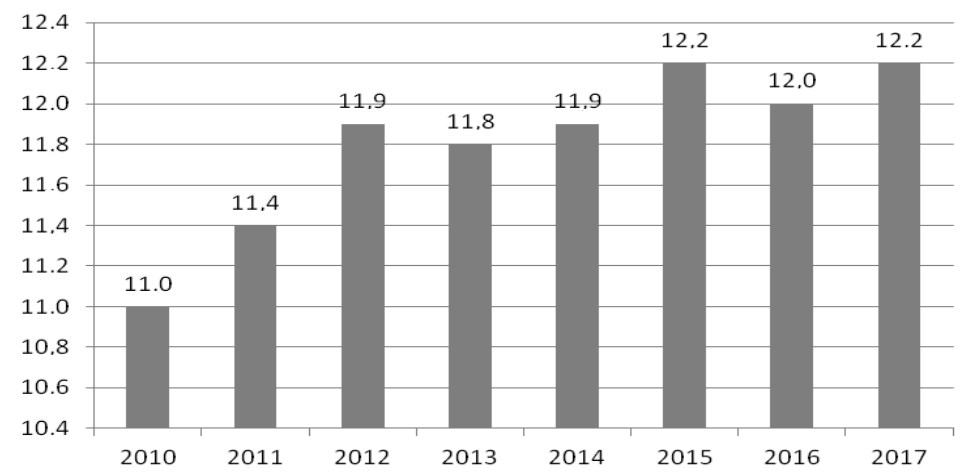

Source: own elaboration on the basis of: [Baza sieci detalicznych, 2018].

\section{Discount stores}

The format of discount stores is characterized by substantial market share and high dynamics of growth. Therefore, one may assume that operators in this format play a crucial role in the process of concentration of the food market in Poland. The market activity of all four discount networks is based on organic growth by means of opening of new trading posts. It needs to be observed that the growth dynamics of these networks are subject to gradual weakening. It results chiefly from the increasing level of the market saturation and considerably stronger competition of the entities operating in other trading formats.

CHART 6

The value share of discount stores in the retail food market in the years 2010-2017 (\%)

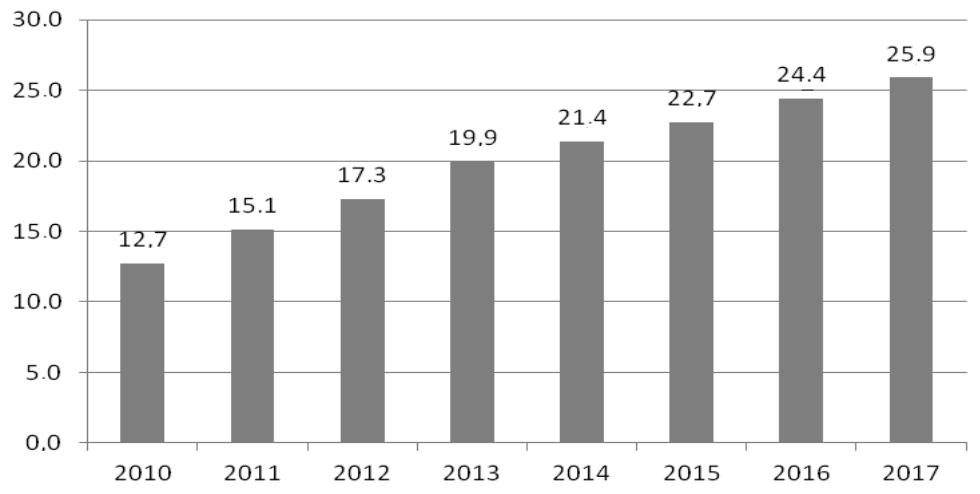

Source: own elaboration on the basis of: [Baza sieci detalicznych, 2018]. 


\section{Convenience stores}

Convenience networks on the Polish market present the largest dynamics, both in terms of the increase in turnover and the number of new trading posts. The operators functioning in this format take advantage of strong social trends, including those regarding the consumers' inclination to impulse shopping. The factor that favors the development of this format is the increase in consumers' remunerations, the result of which is the decreasing price sensitivity. Convenience stores still constitute an insignificant part of the food market, as the result of which their share in the concentration processes is still limited.

CHART 7

\section{The value share of convenience stores in the retail food market in the years 2010-2017 (\%)}

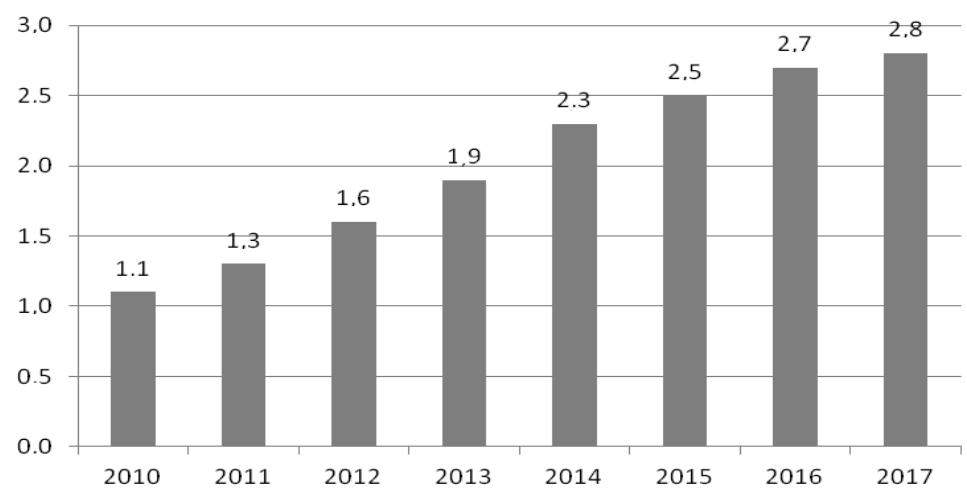

Source: own elaboration on the basis of: [Baza sieci detalicznych, 2018].

\section{Small-format stores}

The share of small-format stores in the retail food market is continuously decreasing. Many smaller trading posts are unable to compete with large-format networks in terms of prices [Koncentracja $i$ konkurencja..., 2005, p. 8]. However, there may be observed the phenomenon of gradual weakening of regression in this format. It results chiefly from the increasing level of competitiveness in terms of the prices, organization and quality of smaller trading posts. This is the direct effect of the dynamic development of franchising networks that comprise the increasing number of small, medium-sized and large food stores. The concentration in the form of franchising is presently becoming one of the most intensive phenomena on the Polish food market. Small-format stores make use of the social trends regarding the preference of frequent purchases in the consumers' place of residence. 
CHART 8

\section{The value share of small-format stores in the retail food market in the years 2010-2017 (\%)}

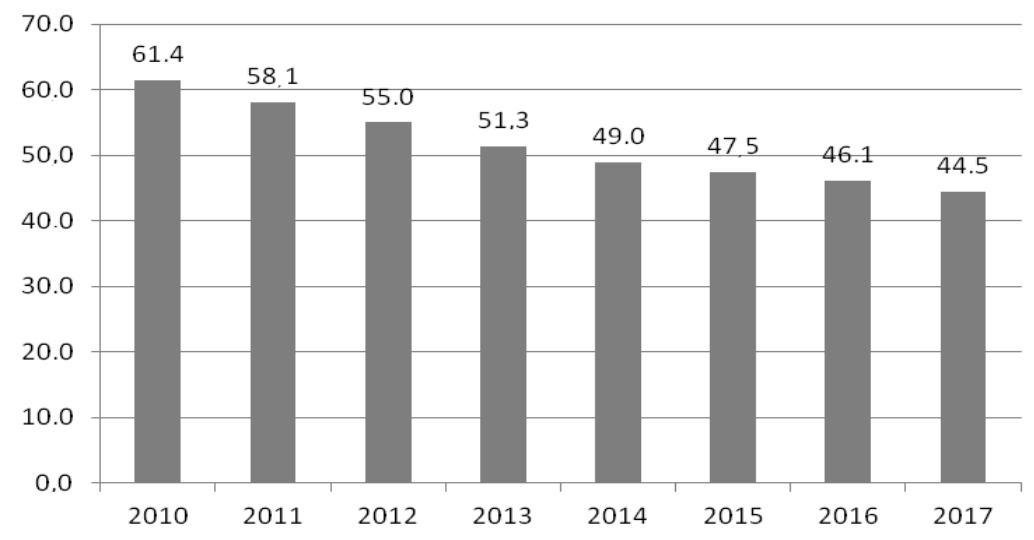

Source: own elaboration on the basis of: [Baza sieci detalicznych, 2018].

\section{The evaluation and social consequences of the market concentration}

The literature concerning economics presents various viewpoints in the context of the implications of concentration on the sector and the purchasing behaviors of the consumers [Czerwonka, Pankau, 2005, p. 292]. The dominating thesis implies that concentration is a natural phenomenon on saturated competitive markets. Simultaneously emphasis is laid on its positive symptoms, taking into consideration especially the higher effectiveness of the activity realized by large market operators. Apart from the increase of effectiveness (with reference to retail trade), there are listed such positive effects of concentration as:

- the reinforcement of competitiveness in terms of the prices and quality,

- the professionalization of the market owing to the reduction of the number of trading operators,

- the improvement of the quality and efficiency of consumer service,

- the shaping of new patterns of purchasing behaviors of consumers,

- the implementation of innovations and modern technological solutions [Kwartalnik Antymonopolony..., 2015, p.18].

The inevitability of further increase of the level of market concentration may not be associated solely with the observation of positive aspects. The high level of this phenomenon may lead to the stable competitive advantage of the largest companies, both in the perspective of the branch and the territory [Kucharska, Twardzik, 2007, p. 85]. The considerable difference of the market force between the largest entities and the smallest ones in a practical sense may hinder efficient combat of smallformat stores in the competition battle. It results chiefly from the major differences in the activity scale, which is connected with the clear advantage of the largest 
operators in terms of the supply, investments, promotion and technologies. The increasing retail market concentration may lead also to the aggregation of the supply offer in the limited number of market operators. In retail trade, it may result in the increasing importance of the leading brands and considerably smaller diversification of the offer on the local level [Kondej, 2006, p. 223]. The negative effect of reducing market competition on the centralized market may be also the inclination of large operators to increase prices, to unify or even lower the quality of the product assortment or to make use of the negotiating advantage in the relations with suppliers. ${ }^{8}$

Therefore, there is a certain conflict of interests between the large retail companies concentrating the market and the consumers. Purchasers are interested in possibly the largest diversification of the retail market, where there is a place for the stores functioning within various trading formats. It regards also an appropriate number of retail points, which enables not only the fast pace and convenience of shopping, but also the versatility of the product offer [Handel we wspótcresnej...., 2016, p. 207].

\section{Conclusions}

On the retail food market in Poland there are observed considerable structural transformations. They lead to a continued reduction in the number of stores and at the same time to increase in the total sales surface. This is the effect of concentration actions undertaken mainly by transnational trading corporations functioning on the Polish market. The phenomenon of concentration shows positive dynamics in the analyzed years 2010-2017. The market share of the largest companies increases thanks to the application of such equal forms of concentration as organic growth, acquisitions, franchising and joint venture.

However, for the last three years, there has been noticed decreasing dynamics of this phenomenon. It results from stagnation in the format of hypermarkets and from the weakening growth dynamics of discount stores. On the other hand, there are intensified concentration phenomena at the level of small-format stores, which are the effect of consolidation activities in the form of franchising undertaken chiefly by large wholesale operators. As the consequence, there are fewer differences in terms of prices, organization, logistics and quality between the large-format and small-format trading posts [Adamowicz, Siedlanowski, 2009, p. 79]. Market concentration in smaller formats leads to the dynamic development of franchising networks, to which small and medium-sized food stores are successively affiliated. Owing to that, the phenomenon of the decreasing number of the total number of food stores presently displays lower dynamics than in previous years. The effect of these activities is the preservation of the diversified structure of Polish market and

8 The example of such activities is Biedronka network, which was previously the price leader, whereas presently (according to the current rankings) it occupies 4-6 position among Polish trading networks [Koszyle cen, 2018]. 
reduction in the dynamics of concentration where the dominating role is played by transnational trading corporations. The characteristic patterns of purchasing behaviors of Polish consumer are beneficial for market diversity. They mostly prefer frequent shopping in medium-sized and small stores located in convenient places [Gazdecki, 2010, p. 7].

The dynamics of the aforementioned phenomena enables one to draw the conclusion: the still progressive phenomenon of concentration will be maintained at the level that will not lead to superfluous domination of the stores belonging to the small group of trading operators. The maintenance of diverse market structure will consumers will preserve the possibility of making choice among various trading posts.

\section{References}

Adamowicz M., Siedlanowski P., 2009, Struktura handlu detalicznego i wrajemne oddriatywania obiektón sieci handlowej (na pryyktadrie miasta Biała Podlaska), Economic and Regional Studies, No. 10(2).

Baza sieci detalicznych, 2018, www.kondejmarketing.com [date of entry: 20.12.2018].

Bishop S., Walker M., 2010, The Economics of EC Competition Law: Concepts, Application and Measurement, Sweet \& Maxwell, London.

Dla polskiego handlu ratunkiem jest konsolidacja, 2016, www.portalspozywczy.pl [date of entry: 22.11.2018].

Domański T., 2001, Strategie marketingowe dusiych sieci handlonych, Wydawnictwo Naukowe PWN, Warszawa.

Driesieć sieci zdominowato rynek, handlowy w Polsce, 2016, www.wiadomoscihandlowe.pl [date of entry: 20.12.2018].

Gardocka-Jałowiec A., 2015, Zmiany konsumpcii a kreowanie innowacji, Wydawnictwo Uniwersytetu w Białymstoku, Białystok.

Gazdecki M., 2010, Koncentracja bandlu detaličnego w Polsce, Journal of Agribusiness and Rural Development, nr 2/16.

Handel we wspótcresnej gospodarce. Nowe wyzpania, 2016, M. Sławińska (ed.), Wydawnictwo Uniwersytetu Ekonomicznego w Poznaniu, Poznań.

Koncentracja $i$ konkurencja w handlu artykutami sposyncryymi i artykutami powszechnego usytteu w Polsce, ze szczególmym unvaglednieniem sieci bandlonych, 2005, Urząd Ochrony Konkurencji i Konsumentów, Warszawa.

Kondej A., 2006, Pržeobrażenia w strukturže polskiego handlu detalicznego na prazykładzৃie Lomìy, [in:] Przedsiebiorczoś́ jako caynnnik rozwoju regionu, A. Chmielak, B. Plawgo (eds), Wydawnictwo Państwowej Wyższej Szkoły Informatyki i Przedsiębiorczości w Łomży, Lomża.

Koszy) cen, 2018, www.dlahandlu.pl/koszyk/ [date of entry: 20.11.2018].

Kowalska K., 2012, Rozwój polskich sieci detalicznych jako sposób ograniczania sity rynkowej miedzynarodowych korporacii bandlowych, Difin, Warsaw.

Kucharska B., Twardzik M., 2007, Koncentracja i integracja w handlu. Aspekt teoretyczny, Wyższa Szkoła Biznesu w Dąbrowie Górniczej, Dąbrowa Górnicza.

Kulisy sprzedaży sklepón Piotr i Pawet do Biedronki, 2018, www.wiadomoscihandlowe.pl [date of entry: 20.11.2018].

Kwartalnik Antymonopolowy i Regulacyiny, 2015, Centrum Studiów Antymonopolowych i Regulacyjnych, nr 5(4), Warszawa. 
Musso F., Druica E., 2014, Handbook on research on retailer-consumer relationship development, IGI Global, London.

Polski rynek handlu spożywczego w 2010-2020 roku, 2016, ww.rolandberger.com [date of entry: 22.11.2018].

Strategie konkurencii w handlu detalicznym w warunkach globalizacji, 2005, M. Sławińska (ed.), Wydawnictwo Akademii Ekonomicznej w Poznaniu, Poznań.

Szulce H., 1998, Struktury $i$ strategie w handlu, Polskie Wydawnictwo Ekonomiczne, Warszawa.

Tandon S., Landes M.R., Woolverton A., 2014, The expansion of modern grocery retailing and trade in developing countries, United States Department of Agriculture, New York.

Urbaniak W., 2004, Wspótczynniki koncentracji w analizie ekonomicznej, Acta Universitatis Lodziensis, Folia Oeconomica, nr 180.

Wspóldziałanie gospodarcze przedsiębiorstw, 1992, J. Lichtarski (ed.), PWE, Warszawa.

www 1, www.zabka.pl [date of entry: 20.11.2018].

Zentes J., Morschett D., Schramm-Klein H., 2011, Strategic retail management, Gabler Verlag, Wiesbaden. 